\title{
Research Paper: Recognition and Analysis of Network Relations in Rural Tourism Through Grounded Theory: A Case Study on Mountainous Valley Route of Haraz, Iran

\author{
Mehdi Hesam $^{1^{*}}$, Mohammad Reza Rezvani
}

1. Assistant Professor, Department of Management, Faculty of Literature and Humanities, University of Guilan, Rasht, Iran.

2. Professor, Department of Human Geography, Faculty of Geography, University of Tehran, Tehran, Iran.

\begin{tabular}{l|l}
$\begin{array}{l}\text { Use yur devictoscan } \\
\text { and read thearticle online }\end{array}$ \\
Grounded Theory: A Case Study on Mountainous Valley Route of Haraz, Iran. Journal of Sustainable Rural Development, 1(1), \\
39-52. https://doi.org/10.18869/nrip.jsrd.1.1.37
\end{tabular}

Article info:

Received: 05 Jan. 2017

Accepted: 31 Mar. 2017
Keywords:

Rural tourism, Network relations, Ground theory, Qualify search, Haraz rural areas route

\begin{abstract}
Purpose: One of the strategies to develop rural regions in most countries is to promote rural tourism. One of the features of rural tourism is its fragmented physical nature; therefore, in recent years, the rural tourism networks are of great concern in this regard. In most countries, the importance of rural tourism networks concept is rising. In the economy of many countries, this concept works better in tourism than other sectors. An analytic approach on rural tourism networks and its application in the development of tourism is essential. One of the most important contributions of tourism is flourishing related and marginal businesses. In the current study and based on ground theory, we attempted to analyze rural tourism networks in mountainous-valley route of Haraz rural areas.
\end{abstract}

Methods: In-depth interviews and group discussions were conducted to collect data. The statistical population consisted of the tourism and related businesses and the samples were selected through the snowball effect sampling method among 216 local businesses. About 35.5 hours were spent to conduct interviews with 40 tourism businesses.

Results: The most important network cooperation is found among the borrowing, manpower, information, consulting, revising, and trade.

Conclusion: In general, the obtained results indicated that regarding business network cooperation, the conditions were not in good condition.
I

\section{Introduction}

$\mathrm{n}$ most rural areas, the economy has declined to a point where the income from traditional agricultural activities has reached below the average per capita point income. Moreover, the Tourism is considered as one of the major factors in the development of countries; and the rural tourism in its specific sense would satisfy the tourist's need and relive the above mentioned problems, if planed and organized properly, by considering the domestic, economic, social, and cultural features (Ghanian, Khani, \& Baghai, 2011).

Tourism is one of the major factors in the development of countries. The rural tourism in its specific sense would satisfy the tourist's need and resolve the above-mentioned problems, if properly planed and organized, i.e., by considering the domestic, economic, social, and cultural features

* Corresponding Author:

Mehdi Hesam, PhD

Address: Department of Management, Faculty of Literature and Humanities, University of Guilan, Khalij Fars Highway, Rasht, Iran.

Tel: +98 (13) 33690485

E-mail: mhesam@guilan.ac.ir 
(Ghanian et al, 2011). Accordingly, rural societies seek measures to create variety in the rural economy. Tourism is one of the major industries with the ability to assist the local economy by creating job varieties in the given area (Allen, Hafer, Long, \& Perdue, 1993; Davis \& Morais, 2004; Hassan, 2000; Long, Perdue, \& Allen, 1990; McGehee \& Andereck, 2004). Employment of the network conception in the tourism literature makes sense and leads to analytic conclusion with respect to objectivity and systemization. Fragmentation in the tourism concept is an old subject of discussion in academic literature (Leiper, 1990; Palmer \& Bejou, 1995; Wang \& Fesenmaier, 2007).

Geographically speaking, tourism attractions are located in regions faraway, where the main markets are small and independent businesses are active in an unorganized working environment. In such regions the survival of the newcomers depends on the group work (Dollinger, 1990). In fact, tourism is a defined system where the interrelations are necessary (Bjork \& Virtanen, 2005). Hence, cooperation among the different tourism goods producers and service providers and institutions is fundamental (Tinsley \& Lynch, 2001). In a sense, the small size of tourism businesses and their segregation force them to join for greater sustainability. Their coexistence contributes to the local economic welfare. Some developed regions due to rural tourism in recent years are located in the Larijan District of Amol City in Mazandaran Province, Iran. The current case study was conducted on the regions where rural tourism is totally evolved. This region is not far from the capital city, Tehran, Mazandaran, Alborz etc., running along the Haraz road with many natural attractive sceneries and numerous visitors. This area was selected with respect to the essence of the tourism business cooperation. In this study, various relations among the local restaurants and influencing factors on them were identified and analyzed.

\section{Literature Review}

Today, tourism is one of the most important endeavors accompanied with changes in the perception of the landscape, manmade/artificial features, sociopolitical and cultural aspects, and lifestyle in general. According to tourism 2020 vision, 604 million tourists all over the world, in 2005 generated more than $\$ 800$ million (transportaion costs not included). The World Trade Organization (WTO) predicts a total of 1561 million travels in 2020. According to the same researchers, tourism can be considered as a new revenue source in enhancing the local economies by creating job opportunities, which can save the rural areas from poverty (Fossati \& Panella, 2000; Giaoutzi \& Nijkamp, 2006; Lee \& Chang, 2008).
In the current study, the restaurants of the study area with their attractive features and year-round operation are of concern. They have high potential to attract tourists, as they are close to big cities and located on the main routes. In this regard, the out-ward aspects and the positive influence of tourism can be formed in the progression of the related businesses by the network and cooperation. The concepts of network and network analysis technology are tools to visualize and analyze the nature of the relationships involved in this realm. These tools provide the method to simplify and make these relationships consistent with one another to achieve effective objectives. Since secluded small entities cannot last long, the network approach would keep them up running (Halme, 2001). The networks, either local, unofficial, or established based on formal agreements, are beneficial for the national regular local tourism organizations, and compensate to the segregated nature of this industry. These network structures satisfy the needs of active sectors in rural tourism and a lot more.

The presented definition of network and network analyeses (social network analysis) consists of an approach and a set of techniques to find sources among the active entities, individual groups, or organizations (Haythornthwaite, 1996). The techniques applied in the network analysis are significantly different from those of the statistical ones which need independent analytical units. Collective network analysis is applied in drawing correlative patterns among the active entities and their structures. The analyses are made by collecting the relevant data, systemizing them in a matrix, and calculating their diversified features such as congestion or centrality. This analysis is beyond a set of analytical strategies and as it deals with the structure, it can be a tool to fit the emotional structures as well. Hence, the network analysis is synonymous for structuralism. The structure among the nodes (the analytical unit in network literature) and the stance of the nodes in the network incorporate judgmental, cognitive, and behavioral consequence for the single units, and the collective ones as a whole. Schmettman et al. (2011) reported that the associations modeling can be used to describe some aspects of the behaviors involved in individuals. Therefore, the network analysis can be considered similar to the theoretical approaches.

Network analysis and scientific methodology constitute the evaluation and recognition of practical relations among the study issues and their structures. These nodes can represent individuals, objects, groups, concepts, occupations, enquiries, feature dimensions, and clusters at different levels. This analysis can describe the external facts as an orderly and condensed network and provide summary saving, retrieval integration, and visualization 
of the data. The perception of network is of 2 widely expanded conceptual schools: the mathematical and social sciences, which somewhat integrated in the mid-20th century. Network analysis in business and economics introduced a new systematic paradigm based on the merits of axiomatic rows. The ongoing studies regarding the networks follow 4 major objectives: 1) recognition of the integration and cohesion of societies or the phenomenon subject to study, 2) recognition of the nodes acting as hinges, 3) recognition of the specific and weird network structures, and 4) finding the answer to how the data are modeled and analyzed (Dooremalen \& Borsboom, 2010). The history of general management and business network is always the center of attention, but in tourism realm it is almost a new concept. Lynch (2000) made an analysis regarding the literature of tourism network and identified some measures beneficial to tourism. They categorized these advantages in learning, trade off, and occupational and associative frameworks (Table 1).

The tourism network constitutes certain groups with common interests and active entities operating at local or regional levels. It is assumed that the thriving network fits the content of Table 1. This can occur at a specific time or period, with respect to the network objectives. The researchers in tourism note that the network analysis is appropriate in this field and also tourism is an excellent networking industry. Tourism is defined as a system where inter-affiliations are necessary (Bjork \& Virtanen, 2005), also cooperation among different institutions and organizations involved in any aspect of tourism on a cooperative business is essential to serve the purpose (Tinsley \& Lynch, 2001). Presence of the network structure is vital in group activities with respect to rural tourism. This almost new phenomenon could improve the tourism business and provide inter-organizational trading, exchange of knowledge, and quality improvement at social level.

\section{Methodology}

The current study adopted the grounded theory methodology, an analytic method to construct the hypothesis through inductive qualitative data (Charmaz \& Bryant, 2010). This method is concerned with constructing the concept in addition to providing a collection of principles for the study process known as total methodology. In the last 4 decades, this method gained a vast popularity as a valuable systematic method to collect and analyze data. It is vastly adopted in business and marketing. The features that distinguish the grounded theory method are as follows: generation of a conceptual framework based on the available data, revealing the main processes in the social realm instead of describing the unit under observation, comparing each datum with whole data, making the data accumulation pattern change possible in the field of study, and promoting the expression of the thoughts about the report as the data collection begins (Papzan, Ghobadi, \& Gravandi, 2010).

This method consists of 5 stages: 1) study design (assessing the technical literature and selecting issues), 2) data accumulation, 3) controlling the data, and drafting the terms and concepts, 4) data analysis, and 5) designing and verifying the model (Ghobadi, Papzan, Zarafshani, \& Geravandi, 2012). The data analysis consists of the open, axiomatic, and selective coding stages (Ghobadi et al., 2012). In the current study, in-depth interviews with centralized groups were done to collect data. The statistical population consisted of 216 potential investors (Table 2) in the study area and the sampling followed the snowball effect method, resulting in the selection of 40 candidates. At least 35.5 hours were spent on interviewing with 40 local businesses to obtain the theoretical notions. The interviews were continued until the data saturation. During the interviews, in addition to

Table 1. The Advantages of a network to establish the objectives of a beneficial tourism

\section{The Benefits of the Network}

Learning and trade off

Cooperative operations in marketing, produce and purchase, promoting the revisiting, encouraging axiomatic enquiry approaches like workers promotion policies, increasing the number of seasonal visitors, best use of small institutions, and supporting the resources, promoting entrepreneurship, intra-network trading, product and service qualify promotion, and participating in occupational expression

The society Developing common objectives, social support of the objectives, reconstructing the social perception in small business investments to achieve the objectives, and earning more income from local revenues

Source: Lynch (2000) 
taking notes, the interviews were recorded, which were very helpful in producing the final manuscript.

The study area consisted of the rural district of Larijan with an area of $1766 \mathrm{~km}^{2}$. Larijan is located in the Southern part of Mazandaran Province (Figure 1). In spring and summer the area population is 70000 , but due to lack of work and proper accommodation and other facilities, in winter time the population reduces to 10000 . The mountainous rural areas are close to the populated urban centers and the main roads; hence, this area has promising potential for expansion of tourism. In recent years, some people of this region built their second homes to accommodate tourists. Moreover, some wealthy people from Tehran built their resort houses in this region. The connecting roads are in good shape; therefore, travels to the northern part of Iran have increased. The tourist related businesses have significantly flourished as well.
In other words, the main constituents of tourist attraction are present here. Mazandaran Province, among the Northern provinces has always had the greatest share in tourism due to its closeness to Tehran, and Alborz region (populated centers) has crowded routes (Haraz, Chaloos, and Firoozkooh highways), and pleasant climate and natural sceneries. The coastal line of this province, the south-western part of the Caspian Sea, used to be the major tourist attraction region, but now its mountainous features are more attractive. Haraz Valley attracts many domestic tourists categorized in 3 major groups:

1. Transit travelers who enjoy the scenery, weather, and all served in a maximum 24 hours. In fact, they cannot be considered as visitors. Most of the villages under study were on Haraz Highway with their shops open to sell domestic farm and dairy products. Restaurants and a variety of service centers are open for travelers, too. The

Table 2. Number and the percentage of businesses in the study zone

\begin{tabular}{|c|c|c|}
\hline Type of Business & Number of Outlets & Percentage \\
\hline Restaurant & 76 & 35.19 \\
\hline Fish market & 8 & 3.70 \\
\hline Butchery & 12 & 5.56 \\
\hline Real estate agency & 15 & 6.94 \\
\hline Super market & 21 & 9.72 \\
\hline Bakery & 7 & 3.24 \\
\hline Mechanic shop & 8 & 3.70 \\
\hline Building material storage & 5 & 2.31 \\
\hline Tea house & 2 & 0.93 \\
\hline Villa for rent by the owner & 9 & 4.17 \\
\hline House of rent by the owner & 9 & 4.17 \\
\hline Hotel & 11 & 5.09 \\
\hline Swimming pool & 9 & 4.17 \\
\hline Souvenir shop & 11 & 5.09 \\
\hline Taxi service & 8 & 3.70 \\
\hline Pilgrimage & 3 & 1.39 \\
\hline Entrance fee & 1 & 0.46 \\
\hline Mountain gear shop & 1 & 0.46 \\
\hline Total & 216 & 100 \\
\hline
\end{tabular}




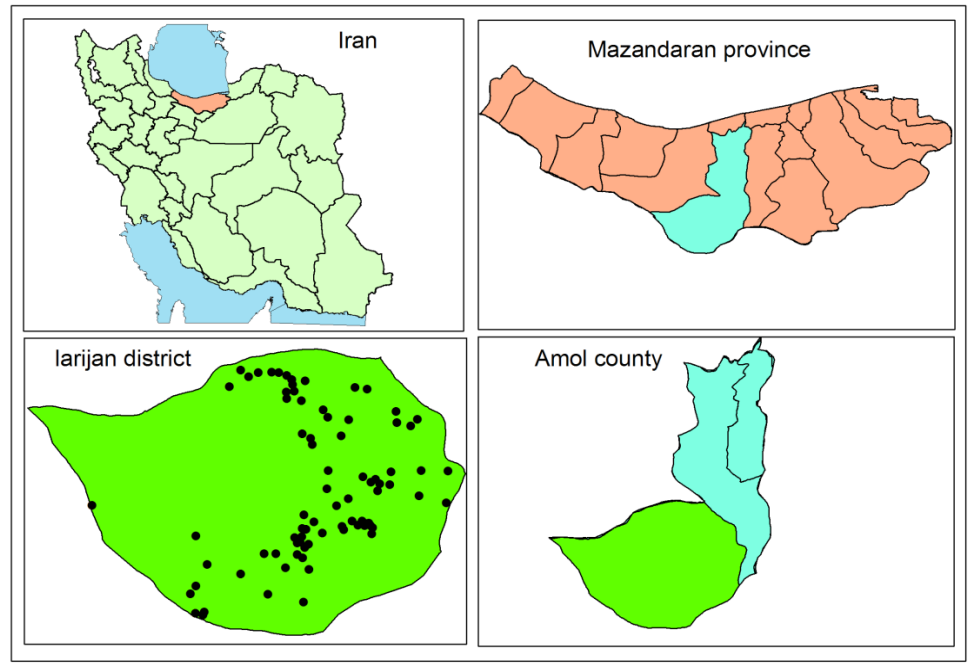

Figure 1. The location of rural areas under study

transit traveler/tourist has less effect on their business; i.e., no significant impact on rural wellbeing. Of course, there are some authentic restaurants on this route and in the villages, which attract customers from far away for their quality food and beautiful scenery.

2. The non-transit travelers with their own accommodation in the rural areas. Naturally, their stay is long and they have to pay for the services provided by the villagers.

3. The ones who come to enjoy the natural beauty of the region and of course pay for the services provided by the villagers. The major services they pay for are accommodation, mineral water treatment centers, retail shops, etc.

The number of business units here is 216 while $10.45 \%$ of which were founded by non-local and the rest by local investors.

\section{Findings}

The collected data were reviewed several times. The issues not related to the subject were eliminated; the main conversations were set in the tables with no categorization, and then, coded through categorized axiomatic manner. In open coding, the statements or the concepts regarding the attractive factors on investment were extracted and coded in 106 items (Table 3). Next, the related concepts were coded in similar frames. The results obtained from open coding based on the concepts were categorized and presented in Table 4 on an axiomatic manner. Based on the findings at open and axiomatic coding stages, the connection among the sections were determined and modeled conceptually (Figure 2).

\section{Discussion}

In tourism industry and in particular the rural tourism, most businesses are small or medium (SMEs) and family oriented with their considerable contributions to the regional economy in all respects. Globalization has put the tourism business under pressure; however, it can provide opportunities for the world free market manipulation. Accordingly, the rural tourism destinations should establish strong networks of cooperation among the tourism business based on the developed strategies to resist the competition on international basis. These networks should operate as a collection of establishments with a common goal. The segregated nature and the variety of the content of this industry are well known that entails the interaction among the beneficiaries with respect to planning and management towards development of this industry.

The initial scientific perception regarding networks indicates cooperation and trust. According to Gray (1989), "cooperation is a joint decision making among the principle beneficiaries regarding a specific issue with respect to the future." For example, the issue here could be planning, marketing and or other activities regarding tourism. Kotler et al. (1993) stated that one of the key factors in establishing a relationship between cooperation and network in promoting and achieving the objectives is what is gained from combining data, expertise, and other resources of the beneficiaries. This cannot be accomplished if there is no trust. Trust can be the basis for individuals' risk-taking, and cooperation with respect to the social order and investment in common (Sztomaka, 1999). Relationships, development, and information 
Table 3. Conceptualization of the available types of connection among the tourism businesses in the study zone

\begin{tabular}{|c|c|c|}
\hline Raw & Connections & Code \\
\hline 1 & Existence of unions in most of the businesses & D1 \\
\hline 2 & Material credibility among the businesses & A1 \\
\hline 3 & Existence of difference of influence among the businesses & $\mathrm{C} 1$ \\
\hline 4 & Financial difficulties among some of the businesses & A2 \\
\hline 5 & Borrowing among some of the businesses & A3 \\
\hline 6 & Most of the business owners were native/local & A4 \\
\hline 7 & Most of the businesses were from the same neighborhood & A5 \\
\hline 8 & Friendship among the business owners & A6 \\
\hline 9 & Closeness of the business outfits & $\mathrm{C} 2$ \\
\hline 10 & Proper access routes among the businesses & E1 \\
\hline 11 & Almost all had transportation means & F1 \\
\hline 12 & They consult one another & D2 \\
\hline 13 & They trade with one another & F2 \\
\hline 14 & Contact one another & E2 \\
\hline 15 & Exchange manpower among each other & B1 \\
\hline 16 & Variety of businesses & D3 \\
\hline 17 & The variety of businesses is high & D4 \\
\hline 18 & Lack of shared marketing & D5 \\
\hline 19 & Lack of shared advertisement & E3 \\
\hline 20 & Separate advertisement & E4 \\
\hline 21 & Direct supply of their products & F3 \\
\hline 22 & Lack of contracts among the businesses & D6 \\
\hline 23 & Lack of using shared brands & E5 \\
\hline 24 & Lack of shared manpower training among the businesses & B2 \\
\hline 25 & Manpower training on individual basis & B3 \\
\hline 26 & Attracting manpower within the same league by promising higher pay & B4 \\
\hline 27 & Strong family relationships among most of the business owners & A7 \\
\hline 28 & Sense of belonging & D7 \\
\hline 29 & Face to face dialogue among the business owners & C3 \\
\hline 30 & Lack of website among the business owners & C4 \\
\hline 31 & Lack of e-mailing among the business owners & C5 \\
\hline 32 & Having one another's contact number & C6 \\
\hline
\end{tabular}




\begin{tabular}{|c|c|c|}
\hline Raw & Connections & Code \\
\hline 33 & Phone contacts & $\mathrm{C7}$ \\
\hline 34 & Domestic youth inclination toward development of infrastructures in tourism & D8 \\
\hline 35 & Proper tourism business outlook & D9 \\
\hline 36 & Possibility to promote non-native investments & D10 \\
\hline 37 & Lack of faculties exchange among the businesses & F4 \\
\hline 38 & Information exchange among the businesses & C8 \\
\hline 39 & Lack of knowledge exchange among the business owners & C9 \\
\hline 40 & Common providers & $\mathrm{C} 10$ \\
\hline 41 & Brand variety & E6 \\
\hline 42 & Participants & A8 \\
\hline 43 & Innovations among the businesses & E7 \\
\hline 44 & Existence of proper regulations regarding tourism & C11 \\
\hline 45 & Most of the business owners are young & A9 \\
\hline 46 & Domestic institutions' support & D11 \\
\hline 47 & Low-cost manpower & B5 \\
\hline 48 & Tax exemption & D12 \\
\hline 49 & No tariff for the services & E8 \\
\hline 50 & Low fluctuation in the influx tourists & E9 \\
\hline 51 & Domestic people's acceptance of the tourist businesses & A10 \\
\hline 52 & Row material production by some of the tourist businesses & F5 \\
\hline 53 & Entrepreneurship concept prevails in the region & $\mathrm{C} 12$ \\
\hline 54 & Providing row material for tourist businesses by one another's assistance & F6 \\
\hline 55 & The age of connecting roads in the region & F7 \\
\hline 56 & High rate of tourist attraction & E10 \\
\hline 57 & Infrastructure services & F8 \\
\hline 58 & Low number of manpower & B6 \\
\hline 59 & High number of visitors during the day & E11 \\
\hline 60 & Most of the owners were male & B7 \\
\hline 61 & Most of the owners had adequate education & C13 \\
\hline 62 & Lack of financial rewards from the cooperation & A11 \\
\hline 63 & Most of the businesses were private & F9 \\
\hline 64 & Separation of the businesses & F10 \\
\hline
\end{tabular}




\begin{tabular}{|c|c|c|}
\hline Raw & Connections & Code \\
\hline 65 & Low non-native investment & A12 \\
\hline 66 & Small size businesses & A13 \\
\hline 67 & Proper approach by the foundations and organizations on investment & D13 \\
\hline 68 & Properly cultured working and producing atmosphere in the region & D14 \\
\hline 69 & The appreciation of investment concept by the business owners & D15 \\
\hline 70 & Strong religious convictions among the business owners & A14 \\
\hline 71 & Regional strategy to assist investments & D16 \\
\hline 72 & The possibility of becoming up to date through new technologies & C14 \\
\hline 73 & Organizing festivals regarding tourism business & C15 \\
\hline 74 & Non-domestic manpower & B8 \\
\hline 75 & High number of tourist groups & B9 \\
\hline 76 & Sudden influx of the tourist groups & B10 \\
\hline 77 & Ranking the businesses of one sector & D17 \\
\hline 78 & Historical attractions & E12 \\
\hline 79 & National attractions & E13 \\
\hline 80 & Lack of expert & B11 \\
\hline 81 & Low number of tourism educated staff & D18 \\
\hline 82 & Lack of study on the interactions among the businesses & D19 \\
\hline 83 & High advertisement fees on domestic TV channels & E14 \\
\hline 84 & Cultural richness of the region & E15 \\
\hline 85 & Natives welcoming visitors & E16 \\
\hline 86 & Strangeness of the visiting parts by the tourists & E17 \\
\hline 87 & High education level of the domestic authorities & C16 \\
\hline 88 & High concern of the authorities towards the study zone & D20 \\
\hline 89 & Discounts on big purchases & F11 \\
\hline 90 & Lack of people-support as institution regarding tourism & C17 \\
\hline 91 & State operated service units for tourists & E18 \\
\hline 92 & Continuous expansion of the connecting roads & F12 \\
\hline 93 & Holy shrine for pilgrimage & E19 \\
\hline 94 & Successful record of the investment experiences & D21 \\
\hline 95 & More inter-guild connection & A15 \\
\hline 96 & Internationally registered moments & E20 \\
\hline
\end{tabular}




\begin{tabular}{|c|c|c|}
\hline Raw & Connections & Code \\
\hline 97 & $\begin{array}{l}\text { Lack of academic knowledge regarding tourism like hotel management, etc., among the tourist business } \\
\text { owners }\end{array}$ & D22 \\
\hline 98 & Low inter-tribal conflicts & $\mathrm{C} 18$ \\
\hline 99 & The young age of the business owners & C19 \\
\hline 100 & High migration rate among the youth in rural areas & B12 \\
\hline 101 & Closeness in interaction & A16 \\
\hline 102 & Public services & E21 \\
\hline 103 & Public access tourism services & E22 \\
\hline 104 & Safe roads in the region & F13 \\
\hline 105 & New investors entering the market & F14 \\
\hline 106 & Constant mutual need among the business owners & F15 \\
\hline
\end{tabular}

Source: Results of the conducted studies

technology are the main subjects discussed and analyzed in the network context.

The resultant of networking includes making necessary data provision and supply, and finding legitimate routes for the information flow (Haythornthwaite, 1996). Tourism is an industry with high interdependencies where evolution is a necessity. Cooperation and correspondence are vital in this industry (Novelli, chmitz, \& Spencer, 2006). The business networks find the essence of these activities in social relationships. Mitchell (1969), the classic sociologist, identified 3 different manners regarding the content of social networks connections: re-

Table 4. Conceptualization of the connections derived from open axiomatic coding

\begin{tabular}{|c|c|c|}
\hline $\begin{array}{c}\text { Expanded Cat- } \\
\text { egory }\end{array}$ & Micro Categories & Statement \\
\hline A) Borrowing & $\begin{array}{l}\text { Material credibility among the businesses } \\
\text { Borrowing among some of the businesses } \\
\text { Most of the business owners are native/local } \\
\text { Most of the businesses are from the same neighborhood } \\
\text { Friendship among the business owners. } \\
\text { Strong family relationships among most of the business owners } \\
\text { Most of the business owners were young. } \\
\text { Lack of financial rewards from the cooperation } \\
\text { Low non-native investment } \\
\text { Small size of the businesses } \\
\text { More inter-guild connection } \\
\text { Contact one another } \\
\text { Participants } \\
\text { Domestic people's acceptance of the tourist businesses } \\
\text { Financial difficulties among some of the businesses } \\
\text { Strong religious convictions among the business owners }\end{array}$ & $\begin{array}{c}\text { "Why should I make problem for myself?" } \\
\text { "It does not worth the risk." } \\
\text { "They all think of their own interests." } \\
\text { "In a mutual trust, I know I will lose." } \\
\text { "Others are smart." } \\
\text { "They will cheat me." } \\
\text { "Trusting them has nothing, but regret." } \\
\text { "I am a trustworthy person." } \\
\text { "You can count on me." } \\
\text { "Most of the colleagues, but my enemies, } \\
\text { trust me." } \\
\text { "The colleagues in restaurant sector are } \\
\text { not trustworthy." } \\
\text { "They envy me." } \\
\text { "I trust my colleagues and I am honest with } \\
\text { them, but they are not." } \\
\text { "Others are not honest." }\end{array}$ \\
\hline B) Manpower & $\begin{array}{l}\text { Exchange manpower among each other } \\
\text { Manpower training on individual basis } \\
\text { Attracting manpower within the same league by Promising } \\
\text { higher wage } \\
\text { Low-cost manpower } \\
\text { Low number of manpower } \\
\text { Most of the owners were male } \\
\text { Non-domestic manpower } \\
\text { Lack of expert } \\
\text { Lack of shared manpower training among the businesses } \\
\text { High migration rate among the youth in rural areas }\end{array}$ & $\begin{array}{c}\text { "Others manipulate my manpower without } \\
\text { my will." } \\
\text { "My worker is a trained and expert one." } \\
\text { "The youth do not like manual works." } \\
\text { "Women have not adapted to working } \\
\text { yet." }\end{array}$ \\
\hline
\end{tabular}




\begin{tabular}{ccc}
\hline $\begin{array}{c}\text { Expanded Cat- } \\
\text { egory }\end{array}$ & Micro Categories & Statement \\
\hline
\end{tabular}

Closeness of the business outfits

Face to face dialogue among the business owners

Lack of website among the business owners

Lack of e-mailing among the business owners

Having one another's contact number

Phone contacts

Information exchange among the businesses

Information exchange among the businesses

Innovations among the businesses

C) Information Most of the owners had adequate education.

The possibility of becoming up to date through new technologies

High education level of the domestic authorities

Lack of people-support as institution regarding tourism Low inter-tribal conflicts

Most of the business owners were young. Common providers

Existence of proper regulations regarding tourism

Organizing festivals regarding tourism business

Existence of difference of influence among the businesses

Low number of tourism educated staff Variety of businesses

The variety of businesses was high Lack of shared marketing

Lack of contracts among the businesses

Properly cultured working and producing atmosphere in the region

The appreciation of investment concept by the business owners Regional strategy for guiding investments

Ranking the businesses of one sector They consult one another.

Lack of scientific studies on the interactions among the busi-

nesses
Successful record of the investment experiences

D) Consulting

Lack of individuals educated on tourism fields such as hotel man-

agement, etc. among the tourist business owners

"I share my information with my colleagues".

"I do not keep any information". "Others do not share their information".

High concern of the authorities towards the study zone

$$
\text { Sense of belonging }
$$

Domestic youth inclination toward development of infrastructures in tourism

Proper tourism business outlook

Possibility to promote non-native investments

Proper approach by the foundations and organizations on investment

Domestic institutions' support

Tax exemption

Existence of unions in most of the businesses

Internationally registered moments

Closeness in interaction

Lack of using shared brands

Financial difficulties among some of the businesses

Entrepreneurship concept prevails in the region

No tariff for the services

Low fluctuation in the tourists influx

High rate of tourist attraction

High number of visitors during the day

State operated service units for tourists

Holy shrine for pilgrimage

Lack of shared advertisement

Separate advertisement

Public access tourism services

Strangeness of the visiting parts by the tourists

"Others do not want to see my progress". "Most often they lie to me".

"Do they know more than I?"

"Others wish my retrogression".

E) Referral

High advertisement fees on the domestic TV channels

Cultural richness of the region

Natives welcoming visitors

Historical attractions

National attractions

Proper access routes among the businesses 


\begin{tabular}{|c|c|c|}
\hline $\begin{array}{c}\text { Expanded Cat- } \\
\text { egory }\end{array}$ & Micro Categories & Statement \\
\hline F) Trade & $\begin{array}{c}\text { Constant mutual need among the business owners } \\
\text { Lack of faculties exchange among the businesses } \\
\text { Separation of the businesses } \\
\text { Continuous expansion of the connecting roads } \\
\text { Safe roads in the region } \\
\text { New investors entering the market } \\
\text { Almost all had transportation means. } \\
\text { Interdependency of many of the businesses } \\
\text { assistance } \\
\text { Rroviding row material for tourist businesses by one another's } \\
\text { Row material production by some of the tourist businesses } \\
\text { Direct supply of their products } \\
\text { Discounts on big purchases } \\
\text { They trade with one another. }\end{array}$ & $\begin{array}{l}\text { "If he decides not to deal with me, it does } \\
\text { not matter at all, as I do not need him". } \\
\text { "Keep the distance, hold the friendship". }\end{array}$ \\
\hline
\end{tabular}

alization of the exchange, correspondence, and the social issues. Ndou and Passiante (2005) expressed that the institutions, when member of a network, can achieve better performance through better opportunities, advances in quality, flexibility, and innovation.

Novelli et al. (2006) believed that expansion of the networks should not be considered as self-sufficient processes, but complex ones where the strong cooperation of the beneficiaries is a must. Scott et al. (2008) evaluated net- work structures in 4 destinations in Australia and found that the information flow among the involved activities constitute the basis to analyze the network for determining its consistency. Isabel-Polo and Dolores (2010) introduced a tourism network in Adolos region, Spain, and distinguished the advantages of such an attempt as better performance of the establishments, improvement of socioeconomic status, and promotion of the general image of the region in the visitors' views. Morrison and Thomas (1999) stated that small businesses face problems such

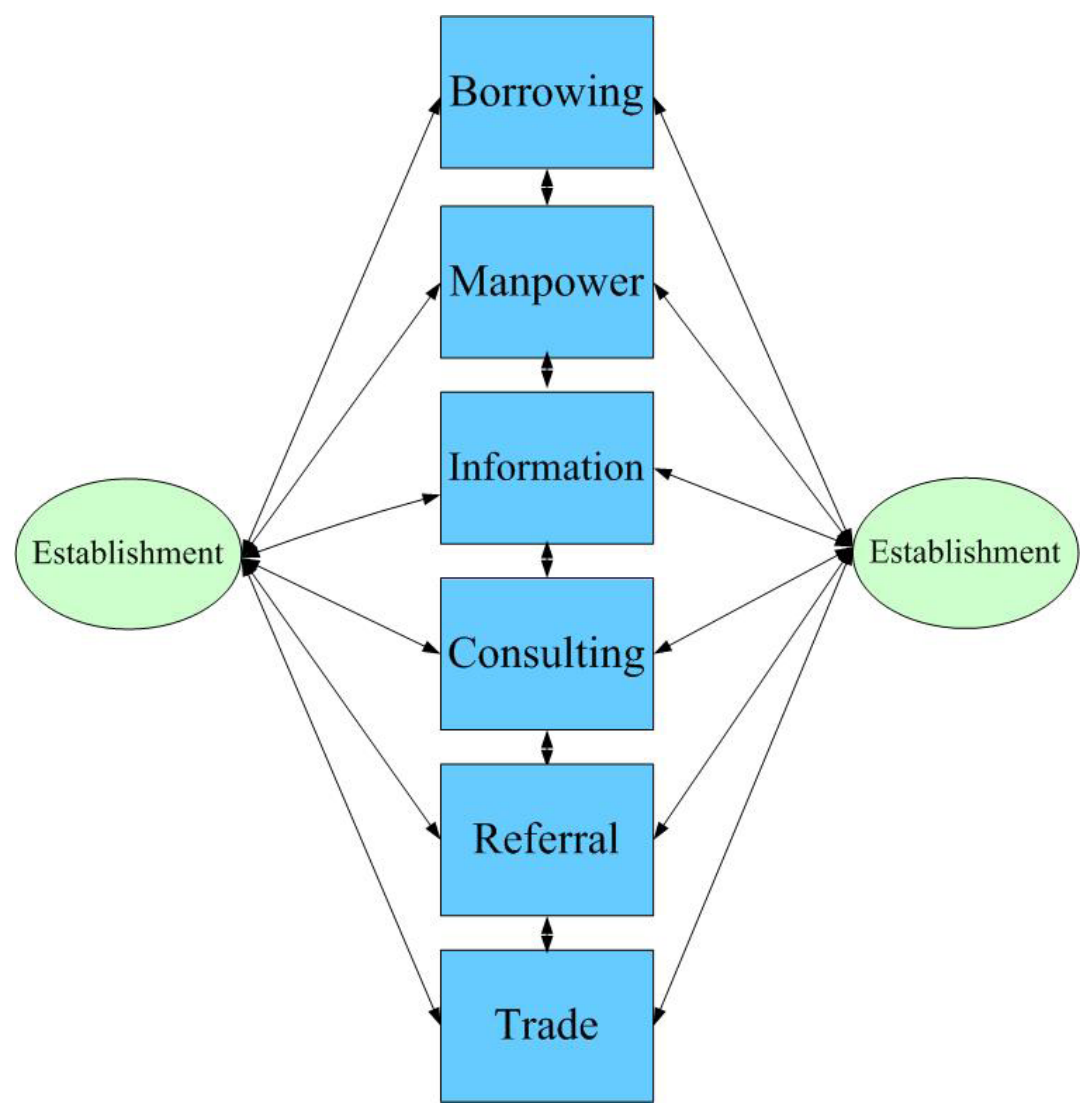

Figure 2. The conceptual model of the study 
as low budget and lack of expert management and marketing. According to Andriotis, lack of knowledge about other occupations, cooperation, and connections in this sector expose small businesses to difficulties.

The current study attempted to evaluate the cooperative state of the restaurants in the study area through network analysis approach and semi-structured interviews during 40 direct interviews lasted at least 35.5 hours which took place in 8 months. We tried to concentrate on major issues such as borrowing, manpower, information, consulting, referral, and trade, as well as the most effective factors such as family relationships, friendship, neighborhood, nativity, membership in cooperatives, trust and hate, accompanied with the connecting channels such as face to face talks, telephone, website, virtual social networks, etc. The first subject of discussion was "borrowing" and the results indicated a sound relationship between the business and the members of their tribes who provided financial support, living more than 100 $\mathrm{km}$ away from the business point. Trust was the most effective factor in "borrowing," in general. In this region, this factor ranked the worst, especially when it came to nonlocal borrowers.

Most business owners said that they did not trust others and preferred to operate alone. More such statements were quoted in the statement column of Table 4. Manpower displacement was the other major factor, especially when they were not native. In these businesses, 24.28\% of the manpower were the members of the same family/ tribe whether from the same local area or city or provinces close by. One of the major drawbacks was their training. For example, when one is trained at the expense of one and then leaves and works for the other for presumably a better pay. It mostly occurs in restaurant industry.

In top rated restaurants, the labor issue is more organized, i.e., there were contracts, insurance coverage, etc. In medium and low rated restaurants, the manpower fluctuates according to the service demand. One of the other major connecting factors is the data exchange among the businesses in areas such as economic (bank inspections), social (public non-material support), political (conventions and cooperative meetings), and so on. This factor prevails at the lower rate businesses. In the association of restaurant owners, the famous ones have the last word regarding their guild. The first grade restaurants, due to their strong management and relationships with the authorities get the first hand information and then pass it down to lower levels. The family ties have an important role in the overall structure of these guild networks.
The obtained results here indicated that work-referral among the businesses was usually a common practice in the low rated restaurants. Food-referral among these restaurants was common as well as satisfying the costumers' needs regarding the type of food. It was the case with top rated restaurants; of course here the high price was the reason for this referral. Consultation on different issues among the businesses was limited, and if there was, it took place within the family circle of the business owners. According to the interviewed subjects, this factor did not progress as there was not enough trust among the business owners. This distrust cannot last long, since as the sense of networking is being promoted, the trust has to prevail. In general, the obtained results indicated that regarding business network cooperation, the conditions were not at average level.

\section{Acknowledgements}

The current research has not received any financial support.

\section{Conflict of Interest}

The authors declared no conflict of interests.

\section{References}

Allen, L. R., Hafer, H. R., Long, P. T., \& Perdue, R. P. (1993) Rural residents' attitudes toward recreation and tourism development. Journal of Travel Research, 31(4), 27-33. doi: $10.1177 / 004728759303100405$

Andriotis, K. (2002). Scale of hospitality firms and local economic development-evidence from Crete. Tourism Management, 23(4), 333-341. doi: 10.1016/s0261-5177(01)00094-2

Björk, P., \& Virtanen, H. (2005). What tourism project managers need to know about co-operation facilitators. Scandinavian Journal of Hospitality and Tourism, 5(3), 212-230. doi: $10.1080 / 15022250510014354$

Charmaz, K., \& Bryant, A. (2010). Grounded theory. In P. Peterson, E. Baker, \& B. McGaw (Eds.). International Encyclopedia of Education (3rd ed.) (pp. 406-412). New York: Elsevier Science.

Davis, J. S., \& Morais, D. B. (2004). Factions and enclaves: small towns and socially unsustainable tourism development. Journal of Travel Research, 43(1), 3-10. doi: $10.1177 / 0047287504265501$

Dollinger, M. J. (1990). The evolution of collective strategies in fragmented industries. The Academy of Management Review, 15(2), 266. doi: $10.2307 / 258157$

Dooremalen, A. J. P. W. \& Borsboom, D. (2010). Metaphors in psychological conceptualization and explanation. In A 
Toomela \& J. Valsiner (Eds.), Methodological Thinking in Psychology: 60 Years Gone Astray? Charlotte: Information Age Publishers.

Fossati, A., \& Panella, G. (2000). Tourism and sustainable development: A theoretical framework. In A. Fossati, \& G. Panella (Eds.), Tourism and Sustainable Economic development (pp. 3-36). Boston: Kluwer Academic Publishers.

Ghanian, M., Khani, F., \& Baghai, L. (2011). [Evaluation of entrepreneurship climate in rural tourism (Case study: Oraman region) (Persian)]. Journal of Rural Research, 2(3), 99-123.

Ghobadi, P., Papzan, A., Zarafshani K., Geravandi S. H. (2012) [The study of rural tourism in Khangha village as perceived by rural villagers: A grounded theory approach (Persian)]. Journal of Housing \& Rural Environment, 31(137), 71-82.

Giaoutzi, M., \& Nijkamp, P. (2006). Emerging trends in tourism development in an open world. Aldershot: Ashgate.

Granovetter, M. (1985) Economic action and social structure: The problem of embeddedness. American Journal of Sociology 91(3), 481-510.

Gravandi, S., Papzan, A., \& Afsharzadeh, N. (2012). Modelling sustainable environmental development using grounded theory (Case-study: Sharveineh Village, Javanroud Township). Journal of Housing \& Rural Environment, 30(136), 67-78.

Gray, B. (1989). Collaborating: Finding common ground for multiparty problems. San Francisco: Jossey-Bass.

Halme, M. (2001). Learning for sustainable development in tourism networks. Business Strategy and the Environment, 10(2), 100-114. doi: 10.1002/bse.278

Hassan,S.S.(2000).Determinantsofmarketcompetitivenessinan environmentally sustainable tourism industry. Journal of Travel Research, 38(3), 239-245. doi: 10.1177/004728750003800305

Haythornthwaite, C. (1996). Social network analysis: An approach and technique for the study of information exchange. Library \& Information Science Research, 18(4), 323-342. doi: 10.1016/s0740-8188(96)90003-1

Isabel Polo, A., \& Dolores, F. (2010). Collective strategies for rural tourism: The experience of networks in Spain. Journal of Tourism Consumption and Practice, 2(1), 25-45.

Kotler, P., Haider, D. H., \& Rein, I. (1993). Marketing places: Attracting investments, industry, and tourism to cities, states and nations. New York: Free Press.

Lechner, C., \& Dowling, M. (1999). The evolution of industrial districts and regional networks: The case of the biotechnology region Munich/Martinried. Journal of Management and Governance, 3(4), 309-338. doi: 10.1023/a:1009928810007

Lee, C. C., \& Chang, C. P. (2008). Tourism development and economic growth: A closer look at panels. Tourism Management, 29(1), 180-192. doi: 10.1016/j.tourman.2007.02.013

Leiper, N. (1990). Partial industrialization of tourism systems Annals of Tourism Research, 17(4), 600-605. doi: 10.1016/01607383(90)90030-u

Long, P. T., Perdue, R. R., \& Allen, L. (1990). Rural resident tourism perceptions and attitudes by community level of tourism. Journal of Travel Research, 28(3), 3-9. doi: $10.1177 / 004728759002800301$
Lynch, P. A. (2000). Networking in the Homestay Sector. The Service Industries Journal, 20(3), 95-116. doi $10.1080 / 02642060000000034$

McGehee, N. G. \& Andereck, K. L. (2004). Factors predicting rural residents' support of tourism. Journal of Travel Research, 43(2):131-140. doi: 10.1177/0047287504268234

Ndou, V., \& Passiante, G. (2005). Value Creation in Tourism Network Systems. Information and Communication Technologies in Tourism 2005, 440-451. In A. J. Frew (ed), Information and Communication Technologies in Tourism. Vienna: Springer.

Novelli, M., Schmitz, B., \& Spencer, T. (2006). Networks, clusters and innovation in tourism: A UK experience. Tourism Management, 27(6), 1141-1152. doi: 10.1016/j.tourman.2005.11.011

Palmer, A., \& Bejou, D. (1995). Tourism destination marketing alliances. Annals of Tourism Research, 22(3), 616-629. doi: 10.1016/0160-7383(95)00010-4

Papzan, A., \& Ghobadi, K., \& Gravandi, S. (2010). Study problems and limitations of rural tourism using grounded theory; The case Harir village. Journal of Rural Research, 1(3), 25-52.

Scott, N., Cooper, C., \& Baggio, R. (2008). Destination networks. Annals of Tourism Research, 35(1), 169-188. doi: 10.1016/j.annals.2007.07.004

Sharpley, R. (2002). Rural tourism and the challenge of tourism diversification: the case of Cyprus. Tourism Management 23(3), 233-244. doi: 10.1016/s0261-5177(01)00078-4

Sztompka, P. (1999). Trust: A sociological theory. Cambridge: Cambridge University Press.

Tinsley, R., \& Lynch, P. (2001). Small tourism business networks and destination development. International Journal of Hospitality Management, 20(4), 367-378. doi:10.1016/s02784319(01)00024-x

World Tourism Organization. (1999). Tourism 2020 vision (Executive summary). New York: World Tourism Organization.

Wang, Y., \& Fesenmaier, D. R. (2007). Collaborative destination marketing: A case study of Elkhart county, Indiana. Tourism Management, 28(3), 863-875. doi: 10.1016/j.tourman.2006.02.007 
